\title{
ANALISIS FAKTOR-FAKTOR YANG MEMPENGARUHI TINGKAT PENGEMBALIAN KREDIT USAHA RAKYAT (KUR) PADA PT. BANK PEMBANGUNAN DAERAH (BPD) SUMATERA BARAT CABANG PAINAN
}

\author{
Dwi Anjeli 1), Jhon Fernos ${ }^{2)}$ \\ 1.2) Akademi Keuangan dan Perbankan "Pembangunan" Padang \\ dwianjeli11@gmail.com
}

\begin{abstract}
The purpose of this study is to determine the analysis of the factors that affect the rate of return on People's Business Credit (KUR) at PT. Bank Pembangunan Daerah (BPD) Sumatera Barat Cabang Painan. This research uses a descriptive method. The results show that there are two factors that affect the rate of return on People's Business Credit (KUR), namely: internal factors that are influenced by the number of loans, credit installments and repayment periods, while external factors are influenced by deteriorating economic conditions.
\end{abstract}

Keywords : Bank, credit, KUR, repayment

\section{PENDAHULUAN}

Berdasarkan UU.NO.10 tahun 1998 tentang perubahan atas UU. No. 7 tahun 1992 pasal 1 tentang perbankan merupakan badan usaha menghimpun dana dari masyarakat dalam bentuk simpanan dan menyalurkan kembali dana tersebut dalam bentuk kredit untuk meningkat taraf hidup (Widayati \& Maiwati, 2019).

Menurut Megawati (2020) pengertian UMKM (Usaha Mikro Kecil Menengah) adalah jenis usaha kecil yang dijalankan oleh masyarakat untuk memenuhi kriteria penjual serta kepemilikan yang berperan penting dalam pembangunan ekonomi nasional. Faktanya pada krisis ekonomi tahun 1997 membuat usaha-usaha besar aktivitas perusahaan menjadi berhenti. Dengan adanya UMKM maka diharapkan krisis tersebut teratasi, UMKM merupakan sektor ekonomi yang banyak dikenal dan diminati para debitur.

Pemerintah merupakan salah satu pihak yang bertanggung jawab terhadap kesejahteraan petani, telah mengeluarkan program kredit atau bantuan modal bagi petani dan para pelaku usaha melalui beberapa pembiayaan salah satunya yaitu Kredit Usaha Rakyat (KUR).

KUR merupakan kredit untuk petani yang diluncurkan oleh pemerintah tanggal 5 November 2007. Program kredit ini guna membantu aksesibilitas kredit para petani yang kemudian dikembangkan melalui kerjasama dengan beberapa bank komersial yang ditunjuk oleh pemerintah dengan plafon kredit sampai dengan 500 juta rupiah serta suku bunga maksimal sebesar 14 persen untuk KUR Ritel dan 22 persen untuk KUR mikro.

Kredit Usaha Rakyat (KUR) merupakan pemberian pembiayaan kepada Usaha Mikro, Kecil, Menengah, Koperasi (UMKM-K) dimana pemberian modal kerja dan investasi dapat mendukung fasilitas penjaminan untuk usaha produktif. 
PT. Bank Pembangunan Daerah (BPD) Sumatera Barat Cabang Painan merupakan salah satu bank yang masih aktif beroperasi di Kabupaten Pesisir Selatan yang memberikan pelayanan kepada masyarakat dalam berbagai bentuk. Salah satu pelayanan yang diberikan oleh bank tersebut adalah pemberian fasilitas kredit. Peningkatan pemberian kredit oleh bank yaitu untuk meningkatkan laba berupa bunga atas pinjaman yang telah diberikan kepada nasabah.

Berikut ini merupakan data jumlah KUR yang disalurkan dan jumlah KUR yang bermasalah pada PT. Bank Pembangunan Daerah (BPD) Sumatera Barat Cabang Painan periode 2018-2020

Tabel 1

Data Jumlah KUR yang disalurkan dan Jumlah KUR Yang Bermasalah Pada PT. Bank Pembangunan Daerah (BPD)

Sumatera Barat Cabang Painan Periode 2018 - 2020 ( dalam Rp. 000 )

\begin{tabular}{ccr}
\hline Tahun & $\begin{array}{c}\text { Jumlah KUR yang } \\
\text { Disalurkan }\end{array}$ & $\begin{array}{c}\text { Jumlah KUR yang } \\
\text { Bermasalah }\end{array}$ \\
\hline 2018 & 42.058 .593 & 270.392 \\
2019 & 56.776 .725 & 1.474 .010 \\
2020 & 72.611 .789 & 545.177 \\
\hline
\end{tabular}

Sumber : BPD Sumatera Barat Cabang Painan, Tahun 2021

Dari tabel 1 diatas dapat diketahui bahwa tahun 2018 sampai tahun 2020 KUR yang disalurkan mengalami peningkatan untuk tiga tahun terakhir. Sedangkan KUR yang bermasalah mengalami peningkatan pada tahun 2019, namun mengalami penurunan pada tahun 2020.

Berdasarkan uraian yang telah dikemukakan diatas maka penulis merumuskan permasalahan yang akan diteliti yaitu bagaimana Analisis FaktorFaktor Yang Mempengaruhi Tingkat Pengembalian Kredit Usaha Rakyat (KUR) Pada PT. Bank Pembangunan Daerah (BPD) Sumatera Barat Cabang Painan.

\section{METODE PENELITIAN}

\section{Metode Pengumpulan Data}

Untuk keperluan penelitian ini, penulis melakukan dua cara pengumpulan data yaitu: a. Teknik Wawancara (Field Research) artinya, penulis bekerja langsung dilapangan untuk melengkapi data-datanya karena dibidang ini cara untuk memdapatkan data melalui Tanya jawab atau wawancara. b. Teknik kepustakaan (Library Research) artinya penelitian dilakukan dengan mempelajari buku-buku, artikel, atau bacaan laporan yang menyangkut dengan objek penelitian.

\section{Metode Analisa Data}

Yaitu menggunakan metode deskriptif dengan menguraikan data yang didapat dan berhubungan dengan faktor-faktor yang mempengaruhi tingkat 
pengembalian Kredit Usaha Rakyat (KUR) pada PT. Bank Pembangunan Daerah (BPD) Sumatera Barat Cabang Painan.

\section{HASIL DAN PEMBAHASAN \\ Pengertian Bank}

Berdasarkan UU Republik Indonesia No. 10 Tahun 1998 tentang perbankan, bank didefenisikan sebagai suatu badan usaha yang menghimpun dana dari masyarakat dalam bentuk simpanan dan menyalurkan kembali dana tersebut kepada masyarakat dalam bentuk kredit atau bentuk-bentuk lainnya demi meningkatkan taraf hidup rakyat (Adnan et al, 2016).

Bank merupakan badan yang bertujuan melayani kebutuhan kredit baik dengan alat pembayaran sendiri atau yang didapat dari orang lain maupun dengan cara mengedarkan alat penukaran uang baru berupa uang giral (Azis, 2014).

\section{Pengertian Kredit Usaha Rakyat (KUR)}

Kredit Usaha Rakyat (KUR) adalah program prioritas pemerintah dalam mendukung UMKM berupa kebijakan pemberian kredit/pembiayaan modal kerja dan investasi kepada debitur individu/perseorangan, badan usaha, atau kelompok usaha yang produktif dan layak, namun belum memiliki agunan tambahan yang cukup. KUR bertujuan untuk tercapainya peningkatan sektor riil dan memperkuat UMKM dalam rangka menanggulangi kemiskinan dan memperluasan kesempatan kerja.

Pada program kredit pemerintah dan BPD Sumatera Barat Cabang Painan menyalur KUR dalam bentuk Kredit Modal Kerja (KMK) maupun Kredit Investasi (KI) dengan plafon kredit maksimal sebesar 500 juta rupiah. Namun, bagi usaha mikro plafon kredit maksimal KUR adalah 20 juta rupiah. KUR dimaksudkan demi meningkatkan akses pembiayaan bagi UMKM yang melakukan usaha produktif dan layak (feasible) namun belum bankable (tidak memenuhi syarat dalam hal agunan serta syarat perkreditan lain yang sesuai dengan ketentuan bank) yang sebagian ditanggung oleh perusahaan penjamin. Usaha Mikro Kecil dan Menengah (UMKM) dijalankan oleh masyarakat untuk memenuhi kriteria penjual serta kepemilikan yang diatur dalam Undang-Undang Republik Indonesia No. 9 Tahun 1995 tentang penjelasan mengenai usaha kecil.

\section{Kriteria Usaha Mikro Kecil dan Menengah ((UMKM)}

a. Usaha Kecil , Yaitu mempunyai kekayaann bersih paling tinggi senilai Rp. 200.000.000,- belum termasuk tanah dan bangunan tempat usaha, dan mempunyai hasil penjualan tahunan paling tinggi senilai $\mathrm{Rp}$ 1.000.000.000,- dan telah berbentuk usaha perorangan.

b. Usaha Menengah Kecil, Merupakan usaha ekonomi yang mempunyai kriteria hasil bersih atau hasil penjualan tahunan lebih besar dari pada hasil bersih dan hasil penjualan tahunan usaha kecil. Berdasarkan instruksi presiden Republik Indonesia No. 10 Tahun 1999 tentang pemberdayaan usaha menengah dengan memberlakukan kriteria usaha menengah yaitu memiliki hasil bersih lebih dari Rp 200.000.000,- sampai dengan paling besar Rp 10.000.000.000,- belum termasuk tanah dan bangunan tempat usaha dan sudah berbentuk usaha perorangan. 


\section{Karakteristik Usaha Mikro Kecil dan Menengah (UMKM)}

Adapun aspek komoditas yang dihasilkan, UMKM memiliki karakteristik tersendiri, yaitu :

a. Kualitasnya belum memenuhi standar, hal ini disebabkan oleh sebagian besar UMKM belum memiliki teknologi yang seragam dan biasanya produk yang dihasilkan dalam bentuk handmade (manual) sehingga dari sisi kualitas relatif beragam.

b. Keterbatasan desain yang dipunya oleh produk UMKM adalah karena keterbatasan ilmu pengetahuan dan pengalaman tentang produk, karena UMKM bekerja berdasarkan pada orderan, tidak beberapa yang berani berkreasi dengan mencoba desain baru.

c. Terbatasnya jenis produk, UMKM hanya akan memproduksi sejenis produk atau produksinya sedikit dan apabila ada permintaan model baru dari buyer sulit untuk dipenuhi karena dalam penyesuaian biasanya waktu yang diperlukan sangat panjang untuk memenuhi order tersebut.

d. Terbatasnya kapasitas atau price list produknya, biasanya kapasitas produk akan lebih sulit menetapkan harga yang tidak terukur kepada konsumen, dan hal ini dapat menyulitkan para pembeli.

\section{Unsur-unsur Kredit Menurut Catur Ps (2014) meliputi:}

1. Kepercayaan, yaitu keyakinan para kreditur kepada debitur dalam memberikan kreditnya dalam jangka waktu tertentu.

2. Waktu, yaitu suatu masa yang diberikan oleh kreditur kepada debitur.

3. Degree of risk, yaitu resiko yang akan dihadapi oleh kreditur dimasa yang akan datang apabila debitur tidak dapat mengembalikan kreditnya.

4. Prestasi, yaitu objek kredit yang diberikan berupa uang ataupun barang.

\section{Tujuan Pemberian Kredit}

Tujuan utama pemberian kredit oleh bank kepada debitur adalah antara

lain:

a. Turut memajukan kegiatan pemerintah pada bidang ekonomi serta pembangunan.

b. Meningkatkan aktivitas perusahaan demi menjalankan fungsinya guna menjamin terpenuhinya kebutuhan masyarakat.

c. Memperoleh laba demi kelangsungan hidup perusahaan agar terjamin serta dapat memperluas perusahaannya.

\section{Pengertian Kredit Bermasalah}

Kredit bermasalah merupakan suatu keadaan dimana nasabah sudah tidak sanggup lagi membayar kreditnya dan seluruh kewajibannya kepada bank seperti yang telah diperjanjikan sebelumnya (Febriansyah \& Afriyeni, 2019).

\section{Penggolongan Kolektibilitas Kredit}

Menurut Oktorita et al (2015) kolektibilitas kredit dapat dibedakan menjadi:

a. Kredit Lancar, adalah kredit yang pembayarannya tepat waktu.

b. Kredit Kurang Lancar, adalah kredit yang angsuran pokok dan bunganya menunggak melampaui 60 hari.

c. Kredit Dipertimbangkan, adalah kredit yang angsuran pokok dan bunganya 
menunggak melampaui 90 hari

d. Kredit diragukan, adalah kredit yang angsuran pokok dan bunganya menunggak melampaui 6 bulan lebih

e. Kredit Macet, adalah kredit yang angsuran pokok dan bunganya menunggak melampaui 9 bulan lebih.

\section{Prinsip-Prinsip Pemberian Kredit}

Prinsip-prinsip pemberian kredit harus mempertimbangkan pengajuan kredit yaitu prinsip 5C dan 7P Anggriawan et al (2017) meliputi: a. Character (Watak), yaitu sifat kepribadian debitur yang berpengaruh saat pemberian kredit, dimana faktor karakter yang menjadi penentu apakah seorang debitur memiliki itikad baik dalam menyelesaikan pembayaran atau malah sebaliknya. b. Capacity (kemampuan), yaitu kesanggupan calon debitur dalam mengembalikan pinjamannya kepada pihak kreditur. c. Capital (modal), yaitu kondisi modal yang dimiliki debitur semakin banyak modal maka semakin besar pula peluang debitur memperoleh kredit, karna debitur akan dipandang yakin untuk menjalankan usahanya. d. Condition of Economy (kondisi perekonomian), yaitu melihat kondisi perekonomian terhadap jenis bisnis yang dijalankan oleh peminjam. e. Collateral (agunan), yaitu jaminan yang diperlukan untuk menjamin pihak debitur.

Selain prinsip 5C, adapun pertimbangan lain yang dilakukan bank berdasarkan prinsip 7P Anggriawan et al (2017) yaitu: a. Personality (kepribadian) mencakup sifat dan kepribadian dari calon peminjam dalam mengajukan permohonan kredit kepada bank. b. Party, adalah mengelompokkan nasabah berdasarkan modal, karakter, atau loyalitasnya. c. Purposive (tujuan) adalah tujuan dari penggunaan kredit yang diajukan oleh calon peminjam kepada bank yang bersangkutan. d. Prospect merupakan prospek usaha perusahaan pada waktu yang akan datang apakah bagus atau tidak, maka bank dapat memprediksi kemampuan bayar dari nasabah. e. Payment (pembayaran) yaitu mengukur bagaimana kemampuan bayar dari calon peminjam, pembayaran dilihat dari kelancaran usaha yang dijalankannya. f. Profitability merupakan cara kemampuan calon debitur dalam menghasilkan keuntungan atau laba. g. Protection adalah mengacu pada jaminan barang, jaminan orang, atau jaminan asuransi yang diberikan oleh calon peminjam.

Kustini (2017) menafsirkan bahwa prinsip 3R digunakan bank untuk memilih calon debitur, prinsip 3R meliputi: a. Returns adalah penilaian terhadap penghasilan yang diperoleh debitur setelah mendapat kredit. b. Repayment merupakan penilaian kesanggupan calon debitur untuk mengembalikan kreditnya sesuai jumlah, jadwal, dan jangka waktu telah ditentukan dalam perjanjian. c. Risk Bearing Ability merupakan penilaian terhadap kesanggupan calon debitur dalam menanggulangi risiko yang timbul apabila terjadi kredit macet.

\section{Pengendalian Kredit}

Menurut Ahmad (2013) pada pengedaran kredit bank perlu memperhatikan sejumlah aspek yang terkait dengan nasabah penerima kredit, demi menghindari terjadinya kredit macet. Oleh sebab itu, pihak bank perlu melakukan pengendalian kredit, yaitu usaha menjaga kredit yang diberikan tetap lancar, produktif, dan tidak macet. Lancar, produktif, dan tidak macet merupakan kredit beserta bunganya sudah diberikan oleh debitur dan dikembalikan sesuai dengan perjanjian 
yang telah disetujui oleh kedua belah pihak. Penyaluran kredit harus berdasarkan pada prinsip kehati-hatian serta pengendalian yang baik dan benar supaya tidak terjadi kerugian pada bank yang bersangkutan.

\section{Teknik Penyelesaian Kredit Macet}

Beberapa implikasi yang bisa saja terjadi jika pihak bank bisa mengatasi kredit bermasalahnya supaya tidak mengalami kerugian. Menurut Suputra (2017) pihak bank dapat melakukan beberapa tindakan penyelamatan dengan cara berikut ini:

a. Rescheduling, tindakan bank melakukan penyelamatan dengan cara memberikan kompensasi waktu, yang artinya waktu kredit diperpanjang dengan membayar administrasi sehingga diberikan lagi jangka waktu untuk membayar hutangnya.

b. Reconditioning, dengan cara memberikan kebijakan pembayaran pokok dan bunga angsuran kredit, yang seharusnya dalam ketentuan harus bayar pokok dan bunga angsuran tetapi diberikan kebijaksanaan untuk membayar bunga saja terlebih dahulu.

c. Restructuring, yaitu dengan cara meningkatkan kemampuan debitur dalam membayar pokok dan bunga jaminan melalui langkah kompensasi sesuai ketentuan yang ada.

\section{Analisis Faktor-Faktor Yang Mempengaruhi Tingkat Pengembalian Kredit Usaha Rakyat (KUR) Pada PT. Bank Pembangunan Daerah (BPD) Sumatera Barat Cabang Painan}

\section{Faktor-Faktor yang Mempengaruhi Tingkat Pengembalian Kredit Usaha Rakyat (KUR)}

Adapun faktor yang dapat mempengaruhi tingkat pengembalian Kredit Usaha Rakyat (KUR) adalah :

a. Faktor internal

Merupakan faktor yang berasal dari bank maupun dari nasabah itu sendiri. Ada beberapa faktor yang sangat berpengaruh terhadap pengembalian Kredit Usaha Rakyat (KUR) yaitu:

1) Jumlah pinjaman

Adalah batas jumlah kredit yang diberikan oleh bank kepada debitur. Faktor yang sangat berpengaruh terhadap kelancaran pengembalian kredit, semakin besar jumlah pinjaman yang diterima oleh debitur maka semakin besar jumlah angsuran dan bunga yang harus dibayarkan sehingga mempengaruhi kelancaran pembayaran pinjaman.

2) Angsuran Kredit Merupakan jumlah angsuran pokok dan bunga yang harus dibayarkan oleh debitur setiap bulannya kepada dalam jangka waktu yang telah ditentukan. Semakin besar angsuran yang harus dibayarkan debitur maka akan semakin sulit debitur membayar angsurannya.

3) Jangka Waktu Pengembalian Kredit 
Adalah batas waktu yang diberikan oleh bank kepada debitur untuk membayar pinjamannya hingga lunas dan faktor yang berpengaruh terhadap pengembalian kredit yaitu semakin lama jangka waktu pengembalian kredit yang diberikan bank kepada debitur yaitu dapat memperkecil tunggakan.

b. Faktor eksternal

Merupakan faktor yang berasal dari lingkungan sekitar, contohnya: dalam segi ekonomi. Dimana wabah yang melanda menyebabkan kondisi ekonomi tersebut menjadi memburuk, sehingga mempengaruhi ekonomi negara dan masyarakat.

\section{Persyaratan Kredit Usaha Rakyat (KUR)}

Persyaratan Kredit Usaha Rakyat (KUR) yaitu sebagai berikut:

a. Calon debitur merupakan individu yang melakukan usaha produktif dan layak.

b. Calon debitur mempunyai legalitas yang lengkap dengan adanya KTP/SIM dan Kartu Keluarga.

c. Menjalankan usaha secara aktif minimal 6 bulan.

d. Plafon kredit tertinggi Rp 20 juta

e. Suku bunga efektifnya paling tinggi 22 persen per tahun.

f. Jangka waktu dan jenis kredit, untuk Kredit Modal Kerja (KMK) maksimal 3 tahun dan Kredit Investasi (KI) maksimal 5 tahun.

g. Pada masa perpanjangan, suplesi, dan restrukturisasi jangka waktunya lebih lama, yaitu paling tingg 6 tahun untuk KMK dan 10 tahun untuk KI.

h. Agunan pokok, berupa objek barang atau surat berharga yang sesuai keyakinan pihak bank bahwa proyek yang dibiayai cash flow-nya mampu.

\section{Mekanisme Penyaluran Kredit Usaha Rakyat (KUR)}

Adapun calon nasabah yang ingin mengajukan permohonan KUR harus mengikuti mekanisme penyaluran KUR di BPD Sumatera Barat Cabang Painan yaitu sebagai berikut:

a. Calon nasabah datang ke kantor terlebih dahulu dan bertemu dengan customer service demi mengajukan permohonan KUR.

b. Berkas-berkas pengajuan permohonan KUR dari nasabah akan diserahkan oleh customer service untuk kepala unit agar diperiksa kelengkapannya.

c. Jika berkas sudah lengkap, kepala unit memberikan berkas-berkas tersebut kepada customer service dan lalu memberikannya kepada mantri KUR agar dianalisis.

d. Setelah itu petugas KUR melakukan tinjauan ke tempat usaha nasabah dan menilai kelayakan usahanya.

e. Lalu petugas KUR memberi informasi kepada kepala unit bahwa usaha tersebut layak atau tidaknya untuk mendapatkan pembiayaan, maka keputusan pemberian kredit dilakukan oleh kepala unit.

Nasabah yang telah disetujui untuk mendapatkan pinjaman KUR harus 
mengembalikan pinjamannya dalam jangka waktu yang telah ditentukan sebelumnya. Angsuran pembayaran kredit bisa dilakukan dengan dua cara, yaitu:

a. Membayar angsuran secara langsung kepada teller.

b. Membayar angsuran dengan menitipkan uang pembayaran kepada mantri KUR untuk dibayarkan kepada teller jika antrian teller penuh. Bagi nasabah yang menunggak, mantri KUR akan mendatangi nasabah tersebut dan kemudian nasabah harus membayar angsuran kreditnya melalui mantri KUR yang mendatanginya.

Tingkat Pengembalian Kredit Usaha Rakyat (KUR)

Tabel 2

Tingkat pertumbuhan KUR yang disalurkan dan KUR Yang

Bermasalah Pada PT. Bank Pembangunan Daerah (BPD)

Sumatera Barat Cabang Painan

Periode 2018 - 2020

( dalam Rp. 000 )

\begin{tabular}{ccrrr}
\hline No & Tahun & $\begin{array}{c}\text { KUR yang } \\
\text { Disalurkan }\end{array}$ & $\begin{array}{c}\text { KUR Yang } \\
\text { Bermasalah }\end{array}$ & $\%$ \\
\hline 1 & 2018 & 42.058 .593 & 270.392 & - \\
2 & 2019 & 56.776 .725 & 1.474 .010 & 3,04 \\
3 & 2020 & 72.611 .789 & 545.177 & $(0,71)$ \\
\hline
\end{tabular}

Sumber: BPD Sumatera Barat Cabang Painan, data olahan

Pada tabel 2 diatas dapat diketahui bahwa persentase pertumbuhan KUR yang bermasalah dan KUR yang disalurkan pada tahun 2019 sebesar 3,04\% mengalami penurunan di tahun 2020 sebesar $0,71 \%$, dimana selisihnya untuk dua tahun terakhir adalah sebesar $2,33 \%$. Artinya kredit yang disalurkan oleh bank sudah berhasil mengendalikan kredit bermasalah yang berasal dari pihak debitur.

Berdasarkan tingkat pengembalian kredit di PT. Bank Pembangunan Daerah (BPD) Sumatera Barat Cabang Painan dapat dilihat dari beberapa faktor yaitu faktor internal dan eksternal. Faktor internal dipengaruhi dari jumlah pinjaman, angsuran kredit dan jangka waktu pengembalian. Sedangkan faktor eksternal dapat dilihat dari segi ekonomi, dimana dalam keadaan sekarang adanya wabah yang membuat perekonomian menjadi memburuk. Contohnya pedagang makanan yang biasanya memperoleh pendapatan yang cukup baik. Karena adanya pandemi saat ini, maka pendapatan tersebut mengalami penurunan yang drastis. Akibatnya pedagang tersebut tidak dapat mengembalikan kreditnya.

\section{Langkah-Langkah yang Dilakukan Bank Jika Tingkat Pengembalian KUR Bermasalah}

Langkah-langkah yang dapat dilakukan oleh pihak bank jika tingkat pengembalian KUR bermasalah yaitu:

a. Penagihan rutin dari petugas kredit

Yaitu datangnya petugas kredit dari pihak bank untuk memberikan surat teguran terhadap nasabah dengan adanya 
tenggat waktu dari:

1) 30 hari merupakan surat teguran

2) 30 - 60 hari merupakan surat peringatan pertama

3) 60 - 90 hari merupakan surat peringatan kedua

4) 90 - keatas merupakan surat peringatan ketiga

b. Melakukan restrukturisasi kredit

Restrukturisasi adalah keringanan yang dibantu oleh pihak bank kepada nasabah dalam membayar kreditnya dengan cara melakukan perpanjangan waktu kredit atau memperkecil angsuran kredit, jadi kreditnya debitur tetap masih ada.

c. Melakukan penjualan/lelang agunan (jaminan dari nasabah)

Penjualan/lelang agunan merupakan langkah terakhir yang di ambil oleh bank untuk pengembalian kredit, dimana agunan yang dibantu oleh pihak debitur kepada kreditur akan dilelang untuk pengembalian kreditnya, atau bisa juga pihak debitur menjual sendiri agunannya dan membayar tagihan kreditnya kepada pihak bank.

\section{SIMPULAN}

Berdasarkan data yang didapat dari PT. Bank Pembangunan Daerah (BPD) Sumatera Barat Cabang Painan tingkat pertumbuhan KUR yang disalurkan dan KUR yang bermasalah pada tahun 2019 sebesar 3,04\% mengalami penurunan di tahun 2020 sebesar $0,71 \%$, selisihnya untuk dua tahun terakhir adalah sebesar $2,33 \%$. Artinya kredit yang disalurkan oleh bank sudah berhasil mengendalikan kredit bermasalah yang berasal dari pihak debitur.

Faktor-faktor yang mempengaruhi tingkat pengembalian Kredit Usaha Rakyat (KUR) yaitu faktor internal dan eksternal. Faktor internal dipengaruhi dari jumlah pinjaman, angsuran kredit dan jangka waktu pengembalian, sedangkan faktor eksternal dipengaruhi oleh kondisi ekonomi, dimana keadaan sekarang pandemi membuat perekonomian menjadi memburuk. Contohnya pedagang makanan yang biasanya memperoleh pendapatan cukup baik mengalami penurunan yang drastis dikarenakan oleh pandemi. Akibatnya pedagang tersebut tidak dapat mengembalikan kreditnya.

\section{UCAPAN TERIMA KASIH}

Penulis mengucapkan terima kasih kepada PT. Bank Pembangunan Daerah (BPD) Sumatera Barat Cabang Painan yang telah mengizinkan dan membantu penulis dalam memperoleh informasi. Serta semua pihak yang telahg membantu penulis dalam menyelesaikan artikel ini.

\section{DAFTAR PUSTAKA}

Adnan, A., dkk. (2016). Pengaruh Ukuran Bank, Dana Pihak Ketiga, Capital Adequacy Ratio, dan Loan To Deposit Ratio Terhadap Penyaluran Kredit Pada Perusahaan Perbankan yang Terdaftar Di Bursa Efek Indonesia Tahun 2011-2015. Jurnal Dinamika Akuntansi Dan Bisnis, 3(2), 49-64. https://doi.org/10.24815/jdab.v3i2.5386 
Alanshari, F., \& Marlius, D. (2018). Prosedur Pemberian Kredit KPR Pada PT. Bank Tabungan Negara (Persero) TBK Cabang Pembantu Bukittinggi. https://doi.org/10.31227/osf.io/rsfhc

Amelia, L., \& Marlius, D. (2018). Pengendalian Kredit Dalam Upaya Menciptakan Bank Yang Sehat Pada PT. Bank Pembangunan Daerah Sumatera Barat Cabang Utama Padang. https://doi.org/10.31227/osf.io/kpc64

Anggriawan, I. G. B. F., Herawati, N. T., \& Purnamawati, I. G. A. (2017). Analisis Prinsip 5C Dan 7P Dalam Pemberian Kredit Untuk Meminimalisir Kredit Bermasalah Dan Meningkatkan Profitabilitas (Studi Kasus Pada Pt. Bpr Pasar Umum Denpasar-Bali). Jurnal Akuntansi $\begin{array}{llll}\text { Program S1, 8(2), } & 12 .\end{array}$ https://ejournal.undiksha.ac.id/index.php/S1ak/article/view/11297

Asyari, A., \& Marlius, D. (2021). Proses Penyelesaian Kredit Bermasalah Pada PT. BPD Sumatera Barat Cabang Pasar Raya Padang. https://doi.org/10.31219/osf.io/3hfcr

Azis, E. (2014). Faktor-Faktor Yang Mempengaruhi Tingkat Kepuasan Nasabah Pada Bank Rakyat Indonesia (BRI) Cabang Bone. 6(2), 26.

Ahmad, A. (2013). Tinjauan Efektivitas Penerapan Sistem Pengendalian Internal Pemberian Kredit Pada PT Bank Mega Cabang Makassar. 1-86.

Catur Ps, B. (2014). Pengamanan Pemberian Kredit Bank Dengan Jaminan Hak Guna Bangunan. Jurnal Cita Hukum, II(9), 1689-1699.

Febriansyah, I., \& Afriyeni, A. (2019). Penyelesaian Kredit Bermasalah PT. Bank Pembangunan Daerah (Bpd) Sumbar Cabang Alahan Panjang Kabupaten Solok. 1-14. https://doi.org/10.31219/osf.io/vutmj

Kustini, F. D. (2017). Analisis Faktor 3R dan 5C Dalam Pemberian KPR. Jurnal Ilmu Manajemen Universitas Galuh Ciamis, 4(April), 209-213.

Megawati. (2020). Pengaruh Pertumbuhan Ekonomi dan Usaha Mikro Kecil Menengah(UMKM),2(2),5164.http://literacy.fasanesia.com/index.php/jis/ article/view23

Oktorita, W., Farida, I., dkk (2015). Analisis Tingkat Kredit Macet Pada Pd. Bpr Bank Tegal Gotong Royong (Tgr) Slawi Kabupaten Tegal. Monex: Journal, 09. http://ejournal.poltektegal.ac.id/index.php/monex/article/view/166

Suputra, K. P. (2017). Analisis Strategi Penarikan Kredit Macet Sebagai Faktor Kunci Berdirinya Kembali Lembaga Perkreditan Desa (LPD) (Studi Kasus Pada LPD Desa Pakraman Tamblang, Kecamatan Kubutambahan, Kabupaten Buleleng). JIMAT (Jurnal Ilmiah Mahasiswa Akuntansi) Undiksha, 7(1), 11.

Widayati, R., \& Maiwati, S. (2019). Aktivitas Pemberian Kredit Komersil Pada Bank Nagari Cabang Sijunjung. 1-12. https://doi.org/10.31219/osf.io/fnxaj 